\title{
On vaccines and vaccination: typhoid-paratyphoid fevers
}

\author{
Wally Vella \\ M.D., F.R.C.Path., M.I.Biol. \\ Colonel, Army Medical Services \\ Assistant Professor of Pathology, Royal Army Medical College, Millbank, London, S.W.1
}

\begin{abstract}
Summary
The various preparations of TAB vaccines proposed in the past and/or available for use at present, together with the methods suggested for the vaccination procedures, are described.

The difficulties of interpreting the serologic diagnostic tests (Widal Test) and the possible dangers of vaccination during an epidemic (provocation typhoid) are discussed.
\end{abstract}

\section{Introduction}

The first attempts in this direction were made independently by Sir Almroth Wright (Lancet, 19 Sept. 1896) and by Pfeiffer \& Kolle (Deutsche Medicinische Wochenschrift, 12 Nov. 1896) both of whom inoculated dead cultures of typhoid bacteria into man with no ill-effects and with the result that specific agglutinins and bactericidins made their appearance in the blood of the inoculated men.

In the years following these first attempts at active immunization of man against enteric fever, the progress which was made in connection with the subject is unquestionably due to Sir Almroth Wright, who in addition to his unremitting researches in the laboratory carried out a large number of inoculations with the vaccine which had been devised by him (Report 1912).

\section{Vaccines}

\section{(a) Heat-killed and phenol preserved $(H K B)$}

The currently used TAB vaccine of the British Armed Forces is a suspension of carefully chosen 'smooth' (Grinnell, 1930; Perry, Findlay \& Bensted, 1933, 1934) strains of Salmonella organisms.

The strains in the vaccine constitute a balanced mixture of old 'classical strains' judiciously complemented by 'wild' strains obtained from various corners of the world. I am indebted to the Officer Commanding, The David Bruce (Army Vaccine) Laboratory for the following information on the serotypes and strains used in the current TAB vaccine (Clifford, 1971); the Salmonella typhi com- ponent consists of three strains (Ty2, T15, T18), while the $S$. paratyphi components consist of two of strains each (HA6 and A1; HB3 and B1).

$S$. typhi Ty2 is the best known of these strains, and it is used on a world-wide scale in the prepara- $\infty$ tion of typhoid vaccines everywhere-it was isolated 5 originally from an epidemic of typhoid fever in $\vec{T}$ Russia.

Each strain is cultured on solid trypsinized meat broth agar contained in special flasks (Roux bottles), and the resultant harvest of bacteria is killed by heating at $54^{\circ} \mathrm{C}$ for $1 \mathrm{hr}$ and preserved in $1.0 \%$ phengl 10 saline as a concentrated suspension until requiregd? for the production of the whole vaccine.

Vaccines are dispensed for use either in $0.5-\mathrm{ml}$ ampoules or in 5-ml vials containing the following concentration of bacilli $/ \mathrm{ml}: S$. typhi (three strains $\times 660$ millions); $S$. paratyphi $A$ (two strains $\times 750 \stackrel{\unrhd}{\circledR}$ millions); $S$. paratyphi $B$ (two strains $\times 750$ millions); $\overrightarrow{\overrightarrow{0}}$ thus giving a total of 5000 million bacilli $/ \mathrm{ml}$ pre- served in $0.5 \%$ phenol saline.

Users of this Forces' vaccine should note that this? vaccine is meant for intradermal inoculation, ando contains twice as many bacilli as the ordinary $\mathrm{TAB}$. vaccine issued by commercial manufacturers.

\section{(b) Alcohol-killed and alcohol-preserved}

'Towards the end of the 1939-45 war Leishman's phenolized vaccine was replaced by an alcoholized은 vaccine with supposedly superior immunizing pro- $\rightarrow$ perties. Whether post hoc or propter hoc remains an arguable point, but in fact the incidence of typhoid N thereafter rose sharply to decline to its previous level only when phenolized vaccine was re-introduced.' N (Lancet, 1967.)

In the 1940s an alcoholized vaccine was for $a^{2}$ period much in vogue. This was based mostly on the work of Felix who found that the Vi antigen of $S$. typhi was responsible for the virulence of newly-isolated typhoid bacilli, and that vaccines containing the virulence $\mathrm{Vi}$ factor were highly active in protect- $\overrightarrow{\mathrm{D}}$ ing animals against challenge by virulent bacilli. 
Morcsver, it was shown that the leat-phenol treatmont of the classical HKP vaccire almost wholly inactivated the $\mathrm{Vi}$ content of this popular vaccine, while tl:e $\mathrm{Vi}$ antigen was stable to alcolol treatment.

Accordingly a TAB vaccine was produced with much enthusiasm and great expcctations, made up of bacilli killed by $75 \%$ alcohol, and preserved in $25 \%$ alcohol (Felix \& Pitt, 1941; Felix, 1941; Felix, Rainsford \& Stokes, 1941 ; Climic, 1942; Edsall et al., 1959).

Unfortunately under field conditions th:e alcoholized vaccine did not fulfil its promisc, ard the vaccire was withdrawn. En passant, it is worth noting that the war-tince HKP vaccine prepared with so much care and attention from smooth virulent strains by the Royal Army Medical Corps workers did prove its efficacy under feld conditions in World War II. Thus, from the classic parer by Boyd, then Deputy Director of Pathology, Middle East Forces, it can te seen how the Eritish prisoncrsof-war were safeguarded from the ravages of enteric fever which reigned in the camps of their captors, and how ketter off the Italian prisor.ers-of-war were when the Italian vaccines were replaced by the British Army vaccine, as soon as sufficient supplies of the latter tecame available for victor ard vanquished alike (Boyd, 1943).

\section{(c) Acetone-inactivated and acetone-preserved ( $A K D)$}

The latest vaccine keing now advocated, and

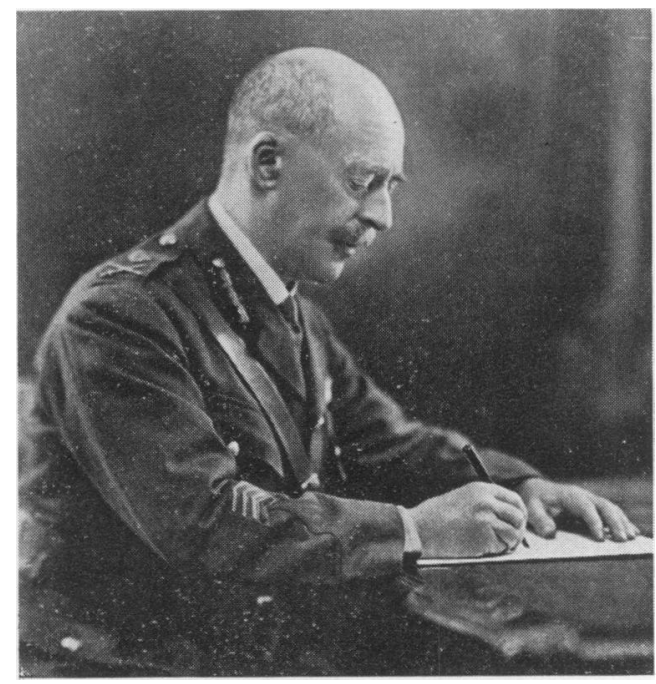

FIG. 1. Sir William Boog Leishman, к.B.c., к.C.M.G.. F.R.S., K.H.P., Professor of Army Pathology, 1903-14; Director of Army Pathology, 1919-23.' A great advocate of TAB vaccine.' Photograph by courtesy of the Commandant, Royal Army Medical College. availablc commercially is an acetone-inactivated vaccine; acetone, like alcohol, also preserves the $\mathrm{Vi}$ antigen (Landy, 1953; Landy et al., 1954).

The bactcria are grown on solid veal infusion agar necdium, the growth is harvested and treated with acetone; inactivation is completed by heating at $37^{\circ} \mathrm{C}$ for $24 \mathrm{hr}$. Th.e bacterial suspension is vacuumdricd and thercfore this vaccine nceds recorstitution with tuffercd sàlire before use.

The AKD vaccincs appear to give a fairly good immunity ard to te ketter than the HKP vaccine; thus in a 7-year field trial of these vaccines in Guyana, Ashcroft et al. (1967) report, 'In 1960 atout 72,000 Guyancse school children, aged 5-15 years, were divided into three similar groups, one of which acted as a control and was given tetanus toxoid, the sccond was given an acetone-killed typhoid vaccine, and the third a heat-killed pt.cnolized typhoid vaccine. Two subcutaneous doses of $0.5 \mathrm{ml}$ of rezonstituted vaccines were given 5 weeks apart. An additional 10,000 children received one dose only. The incidence of typhoid fever, diagnosed by the bacteriological isolation of $S$. typhi, was followed for 7 years after vaccination. In those given two doses, 146 cases of typhoid occurred in the control group, and sixteen and forty-nine in the acetone and heat-phenol typhoid vaccine groups, showing protection rates of 88 and $65 \%$ respectively.

In those given one dose of vaccine the protection was somewhat greater: twenty-two cases occurred in the control group, and one and four in the groups given the acetone and heat-phenol vaccines, respertivcly. Protection showed little diminution until the fifth year after vaccination.'

In more than one country even a single dose of vaccine has given quite good results, which prima facie is surprising considering that these, after all, are inactivated and non-adjuvanted wholc-cell bacterial vaccire; so much so that Ashcroft ct al. quoted above, obscrved that. "It is important that public realth authoritics should kc aware that one dose of a suitable typhoid vaccine can give substantial protection'. There is no doubt that this fact has aroused considerable public interest for example in its possitlc application to protezt holiday makers, tourists and other short-term visitors (Ashcroft, 1969; British Medical Journal, 1970a; Vella, 1970).

The comparative efficacy of these three vaccines descrited in detail above can te briefly stated to te as follow's:

(i) Tle AKD vaccine has teen shown to be generally superior to the other vaccines.

(ii) The HKP vaccine is next in effestiveness to the $A K D$ vaccine.

(iii) The Alc vaccine is inferior to both the above vaccines, and is therefore not rezommended. 
These were the findings of Cvjetanovic \& Uemura (1965) who examined 'the results yielded by a number of collaborative field and laboratory studies of typhoid vaccines conducted under the auspices of the World Health Organization, comparing in particular the results of various controlled field trials carried out in British Guyana, Poland, the U.S.S.R., and Yugoslavia, and attempting to evaluate the effectiveness of the vaccine in man'.

And so finally, more than half a century after their first introduction, the protective value of these enteric fever vaccines has been fully vindicated, certainly as far as the typhoid component of the polyvalent TAB vaccine is involved.

The same conclusions cannot be made with confidence for the other two components (or three components, if $S$. paratyphi $\mathrm{C}$ is included as in TABC vaccine), that is to say for $S$. paratyphi A and $S$. paratyphi B antigens, which were introduced during World War I (1916) and have been incorporated in vaccines more or less traditionally by manufacturers of enteric fever vaccines.

'The entire justification for the addition of the paratyphoid A and B components to typhoid vaccine was the observation that inclusion of these components resulted in the appearance of specific antibodies' (Davison, 1918).

Possibly due to the milder form of enteric fever induced by paratyphoid bacilli as compared with the disease evoked by $S$. typhi, very little work comparatively speaking appears to have been done in the past to investigate under full field conditions the respective value of the paratyphoid bacilli components and so as to justify their inclusion in the popular TAB vaccine.

It is true that work in the U.S.S.R. has shown that it is possible to achieve protection against paratyphoid B by a suitable vaccine, and the conclusion was reached in the trials conducted in that country that 'the data obtained provide a basis for the effective use of immunization against paratyphoid B as part of a set of measures for the prevention of the disease where this is called for by the epidemiological situation' (Hejfec et al., 1968).

Nevertheless, one supposes that the ready availability of antibiotics, to which these organisms are susceptible, in most countries militates against time, money and effort being expended by investigators to gauge their efficacy, hence the tendency nowadays is towards the production of a potent monovalent typhoid vaccine. This is the opinion, for example, held in the U.S.A., 'the effectiveness of paratyphoid A vaccine has never been established, and recent field trials have shown that available paratyphoid B vaccines are not effective, in the usually small amounts contained in TAB vaccines. Knowing this and recognizing that combining paratyphoid $\mathbf{A}$ and

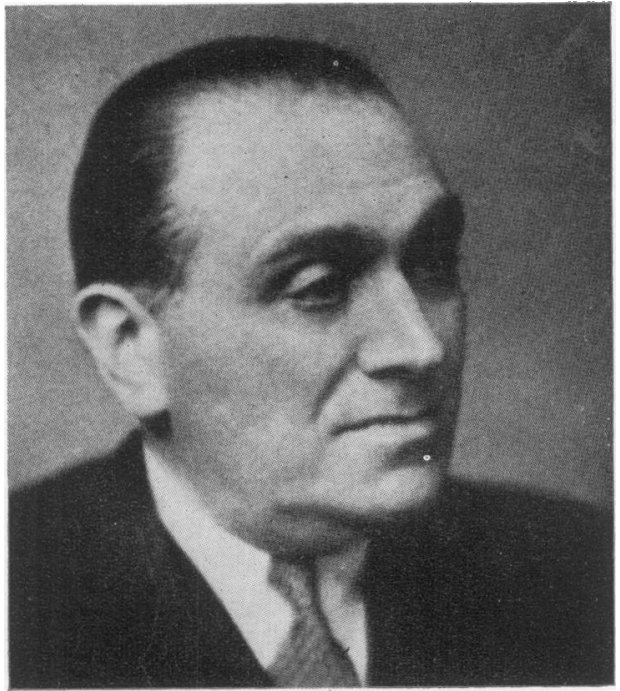

Fig. 2. Arthur Felix (1887-1956), D.Sc., F.R.s. His numerous studies on the $\mathrm{Vi}$ antigen of typhoid bacilli led to a replacement of the old classical vaccines by Vi-containing vaccines. Photograph by courtesy of the Wellcome Trustees.

$B$ antigens with typhoid vaccines increases the risk of vaccine reaction, paratyphoid $A$ and $B$ vaccines should not be used' (Advisory Committee on Immunization Practices, 1969).

The same advice is reiterated from Australia, 'whilst it has been clearly shown beyond question that typhoid vaccines protect well against typhoid, there is no evidence that paratyphoid $\mathbf{A}$ and paratyphoid $B$ vaccine are effective against paratyphoid A or B infections. Furthermore, there is every reason to believe that the paratyphoid A and B components contribute in no small measure to the undue reactivity of TAB vaccine. For these reasons typhoid vaccine is to be preferred to TAB vaccine' (CSL, 1970).

An editorial annotation in the British Medical Journal (28 Feb. 1970) suggests, 'this is perhaps a challenge to the pharmaceutical industry in the United Kingdom to make a potent monovalent vaccine'.

\section{(d) The others}

Besides the bacterial vaccines discussed above there have been numerous other preparations proposed for protection against the enteric fevers (see Vella, 1963) such as:

(i) 'Endotoxoid' vaccine prepared by alternate freezing and thawing of the bacilli and used with success in South Africa. 
(ii) Various antigenic extracts from the bacilli have been prepared both in France and Britain.

(iii) Aluminium hydroxide adjuvanted vaccines in Hungary.

(iv) Formal-chrome preparations in Japan.

\section{Route of administration}

\section{(a) Intradermal vs subcutaneous}

As stated above the TAB vaccine produced by the British Army Vaccine Laboratory is intended to be given intradermally (ID); a separate vaccine, to be given subcutaneously (SCI) is also issued for children under the age of 12 .

Civilian doctors who are used to doing diagnostic skin tests (tuberculin tests, Schick tests, allergy tests) in the skin of the volar surface of the mid-forearm should note that TAB-ID vaccine should not be inoculated in this site, or too many of their patients will complain bitterly about increased local reaction after vaccinations. The skin over the shoulder region is most commonly used, though I have given TAB (and other vaccines) intradermally in the interscapular area on occasions.

Also medical officers should note that AKD is meant to be inoculated SCI or intramuscularly (IM) and not ID.

The British Army changed over from SCI to the ID route of administration in 1958-59 (Home Commands in 1958, Sayers, 1961).

There had been reports published some years previous to this change-over reporting that antibody responses after vaccine administered ID were efficacious and indeed slightly better than when given by SCI or IMI, even when the total dose given was smaller; thus, Tuft (1931a) stated, 'These are all evidences of the fact that in addition to providing mechanical function, the skin also seems to have a specific biological function, designed to protect the internal organs from disease agents possibly by the formation of immune antibodies excited by strong specific skin stimulation'.

Some authors added the rider, though, that the ID method of inoculating the vaccines should be used only in re-inoculation programmes (booster doses) and not in basic primary immunization. It is thought that the efficacy of the intradermal site is due to a slower adsorption of the inoculated antigen and/or abundance of the reticulo-endothelial cells in the dermis (Tuft, 1931b; Tuft et al., 1932; Siler \& Dunham, 1939; Tuft, 1940; Longfellow \& Luippold, 1940; Leibowitz, 1943; Luippold, 1944).

The advantages claimed for the ID method by its protagonists may be listed as follows:

(i) It produces an antibody response equal to that following SCI-one should be very wary, however, of correlating too strictly serum antibodies with the immunity status of an individual. (ii) It evokes fewer reactions than SCI-workers at the Research Laboratories of the U.S.A. Army Medical School, Washington, D.C. commented, 'the reactions that follow re-immunization intracutaneously with $0.1 \mathrm{cc}$ of vaccine are mild in character and of but short duration' (Siler et al., 1941). This observation was noted with great interest by British workers since 'Systemic and local reactions to inoculation against enteric fever have been a cause of much concern in the services for years' (Barr, Sayers \& Stamm, 1959), and the gratifying and satisfactory results following ID route were fully corroborated (Noble, 1963).

(iii) A smaller dose (and therefore more economical) is needed. The ID dose of $0.1 \mathrm{ml}(500$ million bacilli) is usually reckoned to be one-fifth or twofifths that of the equivalent SCI dose (2500 million or 1250 million bacilli) in $1 \mathrm{ml}$ and $0.5 \mathrm{ml}$ respectively. This is fortunate as bigger volumes or greater concentrations of bacilli may give rise to skin necrosis and ulceration (Miles, 1958).

The disadvantages may be stated as:

(i) The more time-consuming technique of ID as against the SCI. In the bad old days when one loaded a syringe with multi-doses of vaccine, the small dose of the ID route was naturally regarded as timesaving and thus logically put forward as an advantage in favour of this method; now, of course, we know better and advise one syringe (disposable) /dose/individual. We can possibly overcome this time-element disadvantage, in this day and age, by the adoption of the Jet (needleless) Vaccination Method.

(ii) Some authors also point out that if due to faulty technique the inoculation is not made properly, 'these doses will fail to protect!' (Davey \& Wilson, 1965).

These points of view are succinctly summed up as follows, 'Primary vaccination with killed vaccines using intradermal jet injection cannot be recommended because all vaccinators may not always be able to implant the entire $0 \cdot 1-\mathrm{ml}$ dose of vaccine in the skin. The intradermal jet may, however, be suitable for vaccination if a satisfactory immune response occurs when most but not necessarily all of the $0 \cdot 1-\mathrm{ml}$ dose of vaccine is deposited in the skin.' Hence, jet injection is satisfactory for booster doses of killed vaccines (British Medical Journal, 1970a, b).

(b) Oral vaccines: local tissue vs systemic protection

Oral killed typhoid vaccine being tested in a controlled field trial contains $10^{11}$ organisms in each dose and three doses are given to each volunteer. The serological studies carried out with this vaccine have shown that it gives rise to circulating antibodies $\mathrm{O}, \mathrm{H}, \mathrm{Vi}$ but preliminary results in a field trial in India, as well as in volunteers, in the 
United States of Ancrica, did not show significant protection.

... Field trials and laboratory studics on animals are under way to elucidate lccal intestinal immunity in entcric infections and possitle applications of oral vaccincs in immunization against typhoid' (World Health Organization, 1964-68).

Newcomers to this field of immunology may think that oral typhoid vaccines are something recent, or even avant garde. It is true that the recent spurt of immunology, which is now a discipline in its full rights, had focused attention on gut immunity in entero-bacterial discases and entero-viral infections, and nasal mucosa immunity in the case of respiratory infections, nciertheless possibly tecause of the case of administration and gereral convenience which would accompany the introduction of a successful oral vaccine, from a comparatively early date in the history of entcric fever vaccines, research wcrkers have experimented and tried their test to produce an efficacious oral vaccine, which may be called th.c immunological equivalent of the contraceptive pill!

Other advantages which would ensuc from this technique of administration are freedom from inoculation hepatitis and post-vaccination reaction.

Thus, we find an oral inactivated vaccine popularized in France fully 50 years ago; Bcsredka (1919-1921) conducted the prcliminary experimental work in animals, 'in experimental typhoid, paratyphoid or dysentery infection in rabbits, he effectivcly immunized the animals by the oral route with living cultures, or with dead cultures given with a dose of bile sufficiently mild to damage the mucosa. From observations that, during repcated oral immunization, agglutinins appeared only transiently in the blood, though the animal continued to te resistant to oral challenge, tee postulated not only that a local immunity had bcen cstablished independently of a gencral response, but that, since the intestire was the chief susceptible tissue in these diseases, the local immunity was the determinant of the general immunity of the animal.'

As can be seen from the WHO Research Programme, 50 years later investigations are still proceeding today under field conditions. As regards dead oral vaccines it has teen shown by a group of Roumanian workers that 'oral administration of a TAB vaccine can afford a considerable degree of protection to young children'. These workers added the rider that antityphoid paratyphoid vaccine by the oral route could be combined with subcutaneous inloculation-the combined of mixed method. This is based on the reasoning that 'after the creation of the local immunity of the intestine, any further increase in general immunity can be obtained only by the introduction of the antigen after a suitable interval by parenteral route' (Vladolanu et al.; 1965).
But oral immunizition with live antityphoid vaccines has teen consideret promising by somc; I assume that if one could tut colonize the human gut with non-pathogcnic coliform crzanisn:s carrying the varied assortment of antigens found in S. typhi and $S$. paratyphi A and B th.cn one could rerinaps make th.c gut protest itself against invasion by th.c entcric fe ver organisms, and in so doing prote $x$ the whole bedy against bacterial invasion which is the prerogative of th.cse dangerous organisms.

One would have to investigatc, of course, the phenom.cna resulting from such intervention, in depth and at length; as in many ott.cr activities in the ficld of medicine, so also in vaccine prophylaxis there may te more than onc facet to this problc.n. Thus, while onc is apt primarily to think of protective immunity as the end result of giving a vaccinc, it must not te forgotten that the vaccince is sensitized (allergized) by such an intervention, and may mount a disastrous allcrgic reaction, 'against antigcnic products of infecting micro-organisms which otherwise are quitc non-toxic and only tesome pathogenic by virtue of initiating allergic reactions resulting in tissuc damagc'. This is the opinion of Professor Gell and Professor Coombs who cite inter alia the cxperimental work of Matsumura who succezded in producing a shigellosis infection in laboratory animals, normally refractory to Shigell 2 organisms, by first scasitizing th.c.n by colonic infusion with Escherichia coli, serotype 0-13, whici has a common antigen with Shigella flexneri, and the otservations of Buxton and his colicagucs who attributed the pathogencsis and symptomatology of Salmonella gallinarum infextions in birds not so much to toxaemia. as to manifestations of an allergic nature. Similar factors are s'uggested as teing operative in other salmonclla infections including S. typhi infectiors in man (Gcll \& Coombs, 1958).

In expcrimental work carried out in the U.S.A., Cvjetanovic, Mel \& Felsenfeld (1970) conclude that 'live orally administered vaccine prepared from a streptomycin dependent strain of $S$. typhi, especially when administered with small doses of streptomycin, may protect chimpanzces to a certain degree against challenge with live wild-type $S$. typhi'.

For the benefit of the uninitiated it must be remarked that it has been found impossible; unfortunately, to produce in ordinary laboratory animals such as mice, rats, rabbits etc. a typhoid fever corresponding to the human infection; chimpanzees, though expensive; have been found to be the most suitable animals for experimental work with typhoid organisms, and other micro-organisms causing human infections.

\section{The Widal test (serologic tests after vaccination)}

'It is almost impossible to assign positive of 
negative values to arbitrary titres in any agglutination test because of a group of variable factors, such as past history of infection, vaccination, time at which specimen was taken, and naturally occurring agglutinins, ... only a rise in titre over a period of time is definitely significant' (Bailey \& Scott, 1970).

TAB vaccination is followed by a rise of serum antibodies in the vaccine. If the HKP vaccine has been used both $\mathrm{H}$ and Oantibodies will appear in blood, and if AKD vaccine has been inoculated then $\mathrm{Vi}$ antibodies will appear in addition to $\mathrm{H}$ and $\mathrm{O}$ antibodies; this is in consonance with what has been said in previous paragraphs about the characteristics of these two vaccines.

It follows therefore that a successful vaccination and revaccination programme in a community or an organization, though highly advantageous from the preventive medicine point of view, may result in difficulties as regards the interpretation by the bacteriologist of the results obtained in the serologic tests for enteric fever, i.e. the Widal test. Fortunately modern bacteriological methods for the isolation of these organisms are highly successful; nevertheless the Widal test remains a valuable weapon in the serologist's armamentarium (Felix, 1950).

In the Widal test, to a series of doubling dilutions prepared from the patient's serum, various suspensions of bacilli containing $\mathrm{H}$ antigens or $\mathrm{O}$ antigens or Vi antigens are added, mixed and incubated, and observed for agglutination reactions.

\section{(a) $H$ antibodies}

After vaccination these can be detected for many years and hence these are not much in favour as a diagnostic index for salmonellosis, besides once the body has been sensitized a rise of $\mathbf{H}$ agglutinins may also occur in response to any irritation of the immunological mechanism even by non-enteric organisms-hence the anamnestic phenomenon which is a trap for the unwary and causes confusion and misdiagnosis.

'The residual TH antibodies resulting from TAB inoculation interfere seriously with the serological diagnosis of the acute disease. Moreover, the presence of TH antibody in the serum of febrile patients who have been inoculated with TAB vaccine has sometimes resulted in a false diagnosis of typhoid fever' (Anderson \& Gunnell, 1964).

These authors, in a stimulating and thoughtprovoking paper, very ingeniously suggested that a possible way out of these diagnostic difficulties is to (i) produce a vaccine from non-motile strains of typhoid and paratyphoid bacilli-thus eliminating the $\mathrm{H}$ antigens int he vaccine. 'The general adoption of a non-motile vaccine strain will ultimately result in the emergence of a population, immunized against typhoid fever, but unencumbered with post- inoculation TH antibodies.' (ii) Because some patients may never be quite certain of their immunity states, the incorporation of a rare 'exotic' flagellar antigen. 'The corresponding $\mathrm{H}$ suspension could be included in the routine Widal test, and the presence of homologous agglutinins would indicate with certainty that the patient had been inoculated against typhoid fever with the "non-motile" vaccine. This would be detectable even if the patient had previously been inoculated with the vaccines in current use'.

\section{(b) $O$ antibodies}

These disappear moderately rapidly after vaccination, so that the presence in a patient's blood of $O$ antibodies in any notable amount (say over $1 / 160$ ) even in a vaccinated person is significant and would denote a recent infection. The test for $\mathrm{O}$ antibodies becomes progressively and directly more valuable the longer the period of time that elapses after vaccination or revaccination.

'Rarely have $O$ titres as high as $1: 160$ been found in serum of vaccinated individuals unless vaccination against typhoid has been very recent (within 7 months). Agglutination titres with the $\mathbf{O}$ antigen in normal uninoculated persons have usually been low. Occasional high titres may have been due to such persons being carriers' (Hac, Flynn \& Perry, 1939).

\section{(c) Vi antibodies}

HKP vaccines do not compromise to any meaningful extent the diagnostic value of the Widal test since as we have seen the preparation of vaccine by this method damages or denatures almost entirely the antigens of the S. typhi; exactly the opposite holds good for the AKD vaccine whose ' $\mathrm{Vi}$ ' factors are preserved by the acetone treatment.

Therefore, so far as the British Forces are concerned, even though all personnel are inoculated at regular intervals, the use of a ' $\mathrm{Vi}$ ' agglutination suspension in the serological diagnostic tests has much to recommend it; in an uninoculated population this is even more so. If a relatively high titre of $\mathrm{Vi}$ antibodies is detected (and Vi antibodies are not found to the same numerically high figures as those found in $\mathrm{H}$ and $\mathrm{O}$ antibodies) then the patient can be regarded with great probability as having been infected with a Vi-carrying $S$. typhi at the time his serum was taken.

The attention of the reader is drawn to the fact that $\mathrm{Vi}$ antigens are not the sole and unique property of S. typhi; other Salmonellae and Enterobacteriaceae may carry this surface (? capsular) antigen: 'many coliform bacilli contain more $\mathrm{Vi}$ antigen than the average strain of the typhoid bacillus' (Wilson \& Miles, 1964). 
The same applies more or less to $\mathrm{H}$ and $\mathrm{O}$ antigenic factors. These antigenic cross-affinities have posed difficulties in the application of diagnostic fluorescent microscopy to the study of enteric infections (Thomason, Cherry \& Edwards, 1959).

It is my rule of thumb in army bacteriology practice to place great diagnostic value on $\mathrm{Vi}$ titres over $1 / 30$; to regard as of doubtful and little significance titres below $1 / 10$, and to consider all factors and retest sera from patients showing a titre between these values.

To summarize, as far as inoculated persons are concerned.

(a) $\mathrm{H}$ antibodies - often a trap for the unwary.

(b) $\mathbf{O}$ antibodies - useful for diagnosis, titre above $1 / 160$.

(c) Vi antibodies-useful for diagnosis, titres 1/30 and above.

(d) Above all the golden rule of all serologic diagnostic tests should be followed, that is to say, to test under exactly the same conditions, paired specimens of sera, or possibly a series of sera taken at appropriate intervals, and watch for difference in titre, either a significant (four-fold) rise in titre, or less usually a dramatic fall.

\section{Provocation typhoid (vaccination during epidemics)}

'Provocation' typhoid refers to what has been called also the 'negative' phase after vaccination, when for a period the resistance of the body may be lowered as the result of an immunological toxaemic insult consequent upon the administration of the foreign antigens.

To vaccinate or not to vaccinate? This is the question that sooner or later the specialist in preventive medicine has to answer when confronted by an epidemic of enteric fever: '. . . in dealing with a largely unprotected civilian population because of the delay in building up any significant immunity, and possible interference with the diagnostic value of the Widal test, TAB vaccine is not recommended' (Department of Health and Social Security, 1968).

Fortunately the armed forces with their attention to and supervision of TAB vaccination programmes of personnel under their care are in a happier position than most civilian communities and organizations, the advice proferred is that a reinforcing dose of TAB vaccine is to be given to personnel and families. However, in cases of primary vaccination, exception is made in the case of unprotected close contacts with known cases of enteric fever, when vaccination is withheld as the vaccine would be unlikely to establish a useful degree of immunity in time to combat the risk of infection and its administration might be a cause of added danger to an individual already incubating the disease' (Ministry of Defence, 1968). This, in my opinion, is sound advice in accordance with that fundamental principle of medical ethics on which we all have been nurtured-Primum non nocere, above all see that you do no harm! I feel that this advice is to be preferred to that held by another school of thought which either does not accept the initial depression of immunity following vaccination or does not regard this negative phase as a contra-indication to vaccinating persons who may be incubating the disease.

As a matter of fact, much can be said, and has been said on both sides of this dilemma.

In favour of vaccination the 1965 Control of Communicable Disease Handbook, tenth edition, issued by the American Public Health Association, and used extensively as a reference handbook by many doctors in diverse fields of medicine, advised succinctly: 'Immunization of contacts: administration of typhoid vaccine to family, household and nursing contacts who have been or may be exposed to cases or carriers'; whereas this handbook in its 1970 (eleventh) edition is not so dogmatic and leaves the question begging, stating that 'administration of typhoid vaccine in these cases is of dubious value'!

And that veritable Bible of British bacteriologists, Topley \& Wilson's Principles (1964), warns 'There is reason to believe that vaccination during the latter part of the incubation period of the disease may, instead of protecting, induce the opposite result, namely the so-called provocation typhoid. This danger is often decried but there is reason to believe that it is substantial. When typhoid fever begins within 2 days of an injection of TAB vaccine, the onset tends to be sudden and the course in most cases severe'.

The reader who is interested to learn what are the expert pros and cons of this particular facet of TAB vaccination is referred to Sir Graham Wilson's proscriptive compendium on the hazards of immunization from which treatise one can appropriately quote in concluding this paragraph, 'For the present we must leave the question unanswered, at least as far as typhoid fever is concerned' (Wilson, 1967).

\section{Conclusion}

(a) The acetone-inactivated typhoid vaccine (AKD) is the best preparation at present available; it is not possible to say whether or not in the future it will or it will not be supplemented or supplanted by an oral inactivated/attenuated vaccine.

(b) More laboratory experimental work and field studies are necessary as regards the paratyphoid components of the TABC vaccines; on the current opinion these should be:

(i) eliminated from the presently used polyvalent TAB (TABC) vaccine, to lessen undue post-vaccination reactions or 
(ii) specially prepared for organizations, such as the armed forces, members of the diplomatic corps, and individuals belonging to missionary or commercial organizations with world-wide commitments, where a need for these polyvalent vaccines exists; or

(iii) tailor-made for localities where paratyphoid fevers are endemic, or the possibility of an epidemic exists.

\section{References}

Advisory Committee on Immunization Practices (1969) U.S. Department of Health, Education and Welfare. Weekly Report Supplement, 18, 26.

Anderson, E.S. \& Gunnell, A. (1964) A suggestion for a new antityphoid vaccine. Lancet, ii, 1196.

Ashcroft, M.T., Singh, B., Nicholson, C.C., Ritchie J.M., Sobryan, E. \& Williams, F. (1967) A 7-year field trial of two typhoid vaccines in Guyana. Lancet, ii, 1056,

ASHCROFT, M.T. (1969) Immunization against typhoid. British Medical Journal, 4, 556.

Barr, M., Sayers, M.H.P. \& Stamm, W.P. (1959) Intradermal TABT vaccines for immunization against enteric. Lancet, i, 816.

BaILey, W.R. \& Scott, E.G. (1970) Diagnostic Bacteriology, 3rd edn, p. 322. C. V. Mosby and Co., St Louis.

BESREDKA, A. (1919-21) Local immunity, quoted in Topley \& Wilson's Principles of Bacteriology and Immunity, 5th edn, Chap. 52, p. 1468. E. Arnold, London.

British Medical Journal (1970a) Any Questions. Immunity from TAB vaccine. 1, 354.

British Medical Journal (1970b) Jet vaccination. 4, 64.

BoYD, J.S.K. (1943) Enteric group fevers in prisoners of war from the western desert, with special reference to prophylactic inoculation, Jan. 1941 to Feb. 1943. British Medical Journal, 1, 719.

Clifford, W.E. (1971) Personal communication.

Climie, H. (1942) Immunization against typhoid and paratyphoid with alcohol-killed, alcohol-preserved, and heatkilled phenol-preserved vaccine. Journal of Hygiene, 42, 411.

CSL (1970) Commonwealth Serum Laboratories, Medical Handbook. Victoria, Australia.

Cyjetanovic, B. \& Uemura, K. (1965) The present status of field and laboratory studies of typhoid and paratyphoid vaccines. With special reference to studies sponsored by World Health Organization. Bulletin of the World Health Organization, 32, 29.

Cvjetanovic, B., Mel, D.M. \& Felsenfeld, O. (1970) Study of live typhoid vaccine in chimpanzees. Bulletin of the World Health Organization, 42, 499.

DaveY, T.H. \& Wilson, T. (1965) In: The Control of Disease in the Tropics (Ed. by Davey and Lightbody). 3rd edn, p. 46. H. K. Lewis, London.

DAvison, W.C. (1918) The superiority of inoculations with mixed triple vaccine (B typhosus, B paratyphosus $A$ and B paratyphosus B). Bulletin of the World Health Organization, 30, 653.

Department of Health and Social Security (1968) Immunization against Infectious Disease, p. 16. H.M.S.O., London.

Edsall, G., Carlson, M.C., Formal, S.B. \& Benenson, A.S. (1959) Laboratory tests of typhoid vaccines used in a controlled field study. Bulletin of the World Health Organization, 20, 1017.

Felix, A. \& Pitt, M. (1934) A new antigen of B. typhosus. Its relation to virulence and to active and passive immunization. Lancet, ii, 186.
Felix, A., Rainsford, S.G. \& Stokes, J.E. (1941) Antibody response and systemic reactions after inoculation of a new type of TABC vaccine. British Medical Journal, 1, 435.

Felix, A. (1936) The Vi antigens of various Salmonella types. British Journal of Experimental Pathology, 17, 81.

Felix, A. (1941) New type of typhoid and paratyphoid vaccine. British Medical Journal, 1, 391.

FeliX, A. (1950) Standardization of diagnostic agglutination tests of typhoid and paratyphoid A and B fevers. Bulletin of the World Health Organization, 2, 643.

Gell, P.G.H. \& Coombs, R.R.A. (1968) Clinical Aspects of Immunology, 2nd edn, Introductory Chap., pp. xxiv and xxv. Blackwell Scientific Publications, Oxford.

GrinNell, F.B. (1930) A study of the comparative value of rough and smooth strains of $B$. typhosus in the preparation of typhoid vaccines. Journal of Immunology, 19, 457.

HaC, L.R., FlynN, C.S. \& Perry, C.A. (1939) Evaluation of $\mathrm{H}$ and $\mathrm{O}$ antigens in agglutination tests for typhoid fever. Journal of Laboratory and Clinical Medicine, 24, 567.

Hejfec, L.B., Levina, L.A., Kuz'Minova, M.C., Salmin, L.V., Slavina, A.M. \& Vasil'Eve (1968) Controlled field trials of paratyphoid $B$ vaccine and evaluation of the effectiveness of a single administration of typhoid vaccine. Bulletin of the World Health Organization, 38, 907.

LANCET (1967) Typhoid vaccines. Editorial annotation. ii, 1075.

LANDY, M. (1953) Enhancement of immunogenicity of typhoid vaccine by retention of Vi-antigen. American Journal of Hygiene, 58, 148.

Landy, M., Gaines, S., Seal, J.R. \& Whiteside, J.E. (1954). Antibody responses of man to three types of anti-typhoid immunizing agent; heat-phenol fluid vaccine, acetonedehydrated vaccine, and isolated $\mathrm{Vi}$ and $\mathrm{O}$ antigens. American Journal of Public Health and the Nation's Health, 44, 1572.

LeIbowitz, A. (1943) A comparative study of the intradermal and subcutaneous methods for typhoid vaccination. Yale Journal of Biology and Medicine, 15, 609.

LONGFELLOW, D. \& LuPPOLD, G.F.C. (1940) Typhoid vaccine studies. Revaccination and duration of immunity. American Journal of Public Health and the Nation's Health, 30, 1311.

LuIPPOLD, G.F.C. (1944) Typhoid vaccine studies. IX. Intracutaneous versus subcutaneous vaccination for initial immunization. American Journal of Public Health and the Nation's Health, 34, 1151.

Ministry of DefENCE (1968) Memorandum on immunslogical procedures, p. 12. H.M.S.O., London.

Miles, A.A. (1958) The toxicity of intracutaneous TAB vaccine. Journal of the Royal Army Medical Corps, 104, 89.

NoBle, J.E. (1963). Reactions to intradermal TABT and TAB vaccines. Journal of the Royal Army Medical Corps, 109, 178.

Perry, H.M., Findlay, H.T. \& Bensted, H.J. (1933a) Antityphoid inoculation. The role of Bacterium typhosum strain Rawlings. Journal of the Royal Army Medical Corps, 60, 241.

Perry, H.M., Findlay, H.T. \& Bensted, H.J. (1933b) Observations on the variation of $B$. typhosum in vivo. Journal of the Royal Army Medical Corps, 61, 81 .

Perry, H.M., Findlay, H.T. \& Bensted, H.J. (1934a) Observations on the immunizing properties and on the manufacture of typhoid vaccine. Journal of the Royal Army Medical Corps, 62, 161.

Perry, H.M., Findlay, H.T. \& Bensted, H.J. (1934b) Observations relative to the immunological value of different cultures of Bacterium typhosum. Journal of the Royal Army Medical Corps, 63, 1 .

REPORT (1912) Report of the Anti-typhoid Committee, 1912. Short history of typhoid inoculation, p. 5. H.M.S.O., London. 
SAIERS, M.H.P. (1961) Recent develepn:chts in anti-chtcric raccines for the British Army. M.D. Thesis. London University.

Siler, J.F. \& DunhaM, G.C. (1939) Duration of immunity conferred by typhoid vaccine. Results of rc-vaccination by intracutaneous injection of typhoid vaccinc. Amcrican Jotrnal of Public Hcalth and the Nation's Hcalth, 29, 95.

Siler, M.C. ot al. (1941) Imminization to typhoid fever. Mcnographic Series No. 17. Ancric an Jourral of Hygicne.

Thomason, B.M., Cherry, W.B. \& Edivards, R.R. (1959) Staining, bacterial smears $\mathrm{u}$ ith fluoresccnt antibody. VI. Identification of Salmonclla in faecal spccimens. Jcurral of Bacteriology, 77, 478.

TuFt, L. (1931a) The skin as an immunolcgical organ. Jcurnal of Inimunolcgy, 21, 85.

TuFT, L. (193.1b) Active immunizaticn against typhoid fever with particular reference to an intradermal mecthod. Journal of Laboratcry and Clirical Mcdicine, 16, 552.

TufT, L. (1940) Further studies of the intracutancous method of typhoid vaccination. American Journal of Medical Sciences, 199, 84.
Tuft, L., Yagle, Elizaefth M. \& Rogers, S. (1932) Com:parative study of the antitody response after various $\varrho$ m.ethods of adninistration of nixed typhoid vaccinc. $\subseteq$ Journal of Infecticus Discases, 50, 98.

VelLA, E.E. (1963) Chrome typhcid vaccine. Jotrrial of Hygiene, 61, 43.

VELLA, E.E. (19;0) Holiday typhoid and TAB. Erinish Medical Journal, 1, 818.

Vladoianu, I.R., Dimache, G., Antoki, S., Vladolanu, Contanta, Zarma Ortansa (1965) Latoratory tests cn the effectiveness of oral vaccination of young children against typhoid and paratyphoid A and B. Eullctin of the World Health Orgat:ization, 32, 37.

Wokld Health Organizaticn (1964-68) The Madical Rescarch Programme of the Wcrld Health Organization 1964-68. Report by tisc Director-General. Enteric infections, Part II. Con:municable discases, np. 39-40. W.H.O. Geneva, 1969.

Wilson, G.S. (1967) The Hazards of Immurization. Provecation disease, p. 270. Athlone Press, Lcnden.

WILSON, G.S. \& MiLes, A.A. (1964) Prophylactic vaccination during an epidemic. In: Principles of Bacteriology and Immunity, 5th edn, Chap. 68, p. 1865. E. Arnold, Lenden. 